\title{
SELECTED CONTAMINANTS IN FISH AND MUSSELS FROM THE BULGARIAN BLACK SEA
}

\author{
Zlatina Peteva ${ }^{1}$, Stanislava Georgieva $^{2}$, Bernd Krock $^{3}$, Mona Stancheva ${ }^{4}$
}

\begin{abstract}
The presence of polychlorinated biphenyl congeners, organochlorine pesticides and marine biotoxins in the marine environment is important for the evaluation of a potential risk to human health. The purpose of the present study was to determine concentrations of polychlorinated biphenyl congeners (PCBs) and organochlorine pesticides (DDT and its metabolites) in three fish species and mussels (Mytilus galloprovincialis) and marine biotoxins in mussels from the Black Sea, Bulgaria. Concentration of six Indicator PCB congeners, DDT and its metabolites were determined by gas chromatography coupled to mass spectrometry. The mean levels of I-PCBs ranged between $6.78 \mathrm{ng} / \mathrm{g}$ ww and $16.33 \mathrm{ng} / \mathrm{g}$ ww (garfish and bluefish respectively). The sum of I-PCBs in all seafood studied did not exceed the EU maximum level. Hydrophilic marine biotoxins determination was performed by HPLC with postchromatographic oxidation. Lipophilic marine toxins were determined on liquid chromatograph coupled to mass spectrometry. The analyzed marine biotoxins were under the limit of detection.
\end{abstract}

UDC Classification: 543.6; DOI: http://dx.doi.org/10.12955/cbup.v6.1307

Keywords: seafood; mussel; DDTs; PCBs; marine toxins, Bulgaria

\section{Introduction}

Fish and shellfish are considered healthy foods because of their high nutritional value including high levels of poly-unsaturated fatty acids (PUFA), especially omega-3 fatty acids. Recent research on the nutritional characteristics of fish and shellfish from the Bulgarian coast showed high values of unsaturated fatty acids, high protein and high fat-soluble vitamin content (Merdzhanova, 2017; Stancheva, 2017a). Nonetheless, seafood is affected by the accumulation of chemical contaminants, particularly organochlorine compounds and marine biotoxins, and this could become extremely dangerous for the human health (Marques, 2013; Marques, 2010).

Some organochlorine compounds are persistent and although they have been banned, continue to be widespread and accumulate in the marine ecosystem (Turner, 1986). Polychlorinated biphenyls (PCBs), dichlorodiphenyltrichloroethane and its metabolites (DDTs) are well known as persistent substances in the aquatic environment and seafood rapidly accumulates these compounds both through their feeding behavior and from the surrounding environment (Antunes and Gil, 2004; Bordajandi, 2006; Stancheva, 2017b). These toxic substances are listed as persistent organic pollutants (POPs) in The Stockholm Convention (UNEP, 2001).

POPs have a negative effect on the flora and fauna in affected aquatic areas (Naccari, 2004; Zelníčková, 2015). Changes in environmental conditions are likely to influence the spread and behavior of POPs, ultimately affecting aquatic organisms and leading to human exposure (Nadal, 2015).

Fish and mussel are often used to monitor organochlorine contaminants due to their easy sampling, wide geographical distribution and the accumulation of toxic compounds within them (Okay, 2009; Suárez, 2013). Seafood may represent an important exposure route of introducing persistent compounds into the human body (Dorea, 2008; Van Ael, 2012). In contrast to the anthropogenic origin of the POPs, marine toxins are produced by some marine microalgae. Shellfish filter feed suspended algae and food particles from large volumes of water through their bodies and assimilate them. Hence shellfish like mussels have the potential to concentrate phycotoxins at dangerous levels (Huss, 1997) causing severe illness. Marine toxins are divided in groups according the health problems they cause - paralytic shellfish poisoning (PSP, including saxitoxin, neosaxitoxin etc.), amnesic shellfish poisoning (ASP, including domoic acid etc.), diarrhetic shellfish poisoning (DSP, including okadaic acid, dinophysistoxins), and azaspiracid shellfish poisoning (AZP, including azaspiracids - AZA). The particular toxin mixture retained in the soft tissues of the shellfish varies in concentration and over time, and is determined by the species and strains of the dinoflagellates and shellfish as well as by other factors like environmental conditions (Mons, 1998).

\footnotetext{
${ }^{1}$ Medical University - Varna, Department of Chemistry,Varna, Bulgaria, zlatina.peteva@mu-varna.bg

${ }^{2}$ Medical University - Varna, Department of Chemistry,Varna, Bulgaria, stanislavavn@mail.bg

${ }^{3}$ Alfred Wegener Institute, Helmholz Zentrum für Polar- und Meeresforshung, Chemische Ökologie, am Handelshafen 12, 27570 Bremerhaven, Germany, bernd.krock@awi.de

${ }^{4}$ Medical University - Varna, Department of Chemistry,Varna, Bulgaria, mona_stancheva@abv.bg
} 
Detection of contaminated seafood is not straight forward, and neither fishermen nor consumers can usually determine whether seafood products are safe for consumption. Marine biotoxins accumulate mostly in the digestive glands of bivalves, but do not alter the taste of the meat (Ferrante, 2013). For this reason, most countries have established monitoring programs for marine biotoxins through their national agencies for food safety to ensure that contaminated shellfish are not placed on the market.

The aim of this study was to determine the concentrations of selected contaminants - polychlorinated biphenyl congeners (PCBs) and organochlorine pesticides (DDT and its metabolites) in bluefish (Pomatomus saltatrix), garfish (Belone belone), sprat (Engraulis encrasicholus ponticus) and mussels (Mytilus galloprovincialis) and marine biotoxins (PSP, ASP, DSP and AZP) in mussels collected from the Black Sea, Bulgaria.

\section{Materials and Methods}

Fish and mussel (Mytilus Galloprovincialis) samples were collected by professional harvesters from three Bulgarian coastal areas of the Black Sea: North (near cape Kaliakra), Varna (Varna bay) and South (Burgas and Sozopol). The sampling was carried out in late April 2015 to early June 2016 in wild and farmed populations at a sea depth of 3-4 m.

Analyses were carried out on pooled samples of the individual species collected at each sampling point. Every pool contains a different number of individual specimens depending on the species: 10- 40 for fish samples and about 60 specimens for mussel samples. Whole soft tissue from the pooled samples was homogenized and pools of about $200 \mathrm{~g}$ were taken for POPs and $100 \mathrm{~g}$ for marine toxins analysis.

The method used for the extraction and detection of the POPs in fish and mussel samples has been previously described in detail (Stancheva, 2013) and is briefly presented below. The edible tissues of fish were homogenized, and sub-samples of $20 \mathrm{~g}$ were taken for extraction with hexane / dichloromethane in Soxhlet. The lipid extracts were cleaned-up by column chromatography (with neutral and acidic silica). PCBs and DDTs were eluted with $80 \mathrm{ml}$-hexane followed by $50 \mathrm{ml}$-hexane/ dichloromethane $(80: 20 \mathrm{v} / \mathrm{v})$.

Detection of DDTs and PCBs were carried out by GC FOCUS (Thermo Electron Corporation, USA) using a POLARIS Q Ion Trap mass spectrometer, equipped with an AI 3000 autosampler and a TR-5ms capillary column (cross-linked 5\% phenyl methyl siloxane $30 \mathrm{~m}$ x $0.25 \mathrm{~mm}$ ID x film thickness 0.25 $\mu \mathrm{m})$. The carrier gas used was helium at a flow of $1 \mathrm{ml} / \mathrm{min}$.

Pure reference standard solutions (EPA 625/CLP Pesticides Mix $2000 \mu \mathrm{g} / \mathrm{ml}$ - Supelco and PCB Mix 20 - Dr. Ehrenstorfer Laboratory), were used for instrument calibration, recovery determination and quantification of the compounds. Measured compounds were p,p'-DDT, p,p'-DDD and p,p'-DDE and PCB congeners: IUPAC № $28,52,101,138,153,180$ ). The limits of quantification (LOQ) varied for individual compounds from 0.2 to $0.5 \mathrm{ng} / \mathrm{g}$ ww.

The method for extraction and determination of PSP was previously described by Krock (2007). Briefly, $2 \mathrm{~g}$ of mussel tissue was homogenized with $0.2 \mathrm{M}$ of acetic acid. The extract is separated in aliquot 1 and aliquot 2. Aliquot 1 is filtered. Aliquot 2 is additionally concentrated by evaporation and dissolved in $0.1 \mathrm{M}$ hydrochloric acid.

The extracts were analyzed for PSP by reverse-phase ion-pair liquid chromatography with fluorescence detection (LC-FD) and post-column derivatization following minor modifications of the previously published methods. The eluate from the column was oxidized with $10 \mathrm{mM}$ periodic acid in $555 \mathrm{mM}$ ammonium hydroxide before entering the reaction coil $\left(50^{\circ} \mathrm{C}\right)$, after which it was acidified with 0.75 $\mathrm{M}$ nitric acid. The detection of the toxins was performed by dual-monochromator fluorescence ( $\lambda$ ex 333 $\mathrm{nm} ; \lambda$ em $395 \mathrm{~nm}$ ).

The method for extraction and determination of lipophilic toxins (ASP, AZA, DSP) was described in Krock (2008). For the analysis of lipophilic toxins $4 \mathrm{~g}$ of mussel tissue were homogenized with $80 \%$ methanol. The extracts were degreased with n-hexane and further purified with chloroform. After evaporation the residue was taken up in $300 \mu 1$ of $100 \%$ methanol. Six extracts are kept without filtration and six extracts were transferred to a $0.45-\mu \mathrm{m}$ pore-size spin-filtern and centrifuged. The resulting filtrate was transferred into an LC autosampler vial for LC-MS/MS analysis.

Mass spectral experiments were performed on AB-SCIEX-4000 Q Trap, triple quadrupole mass spectrometer equipped with a TurboSpray ${ }^{\circledR}$ interface coupled to an Agilent model 1100 LC. The LC 
equipment included a solvent reservoir, in-line degasser (G1379A), binary pump (G1311A), refrigerated autosampler (G1329A/G1330B), and temperature-controlled column oven (G1316A).

Quality control was carried out by analyses of certified reference materials: BCR - 598 (DDTs in Cod liver oil) and BB350 (PCBs in Fish oil) - Institute for Reference Materials and Measurements, European commission, CRM-DA-g, CRM-OA-d, CRM-PTX2-b, CRM-YTX-c, standard solutions of PSP toxins (saxitoxin, STX, neosaxitoxin, NEO, decarbamoyl saxitoxin, dcSTX, gonyautoxins 1\&4, GTX1/GTX4, gonyautoxins 2\&3, GTX2/GTX3, decarbamoyl gonyautoxins 2\&3, dcGTX2/dcGTX3, and B1) were purchased from the Certified Reference Material Programme of the Institute of Marine Biosciences, National Research Council, Halifax, Canada.

The statistical analysis of the data was based on the comparison of mean values through a t-test, and a significance level of $\mathrm{p}<0.05$ was used. SPSS 16 software was used for the statistical tests.

\section{Results and Discussion}

The concentration of individual compounds p,p'-DDE, p,p'-DDD, p,p'-DDT (ng/g wet weight) and lipid content (\%) found in fish and mussel samples, collected from the Black Sea are presented in Table 1. Among the different organochlorines p,p-DDE is the most abundant in fish samples (in the range from 6.38 to $38,35 \mathrm{ng} / \mathrm{g} \mathrm{ww}$ ).

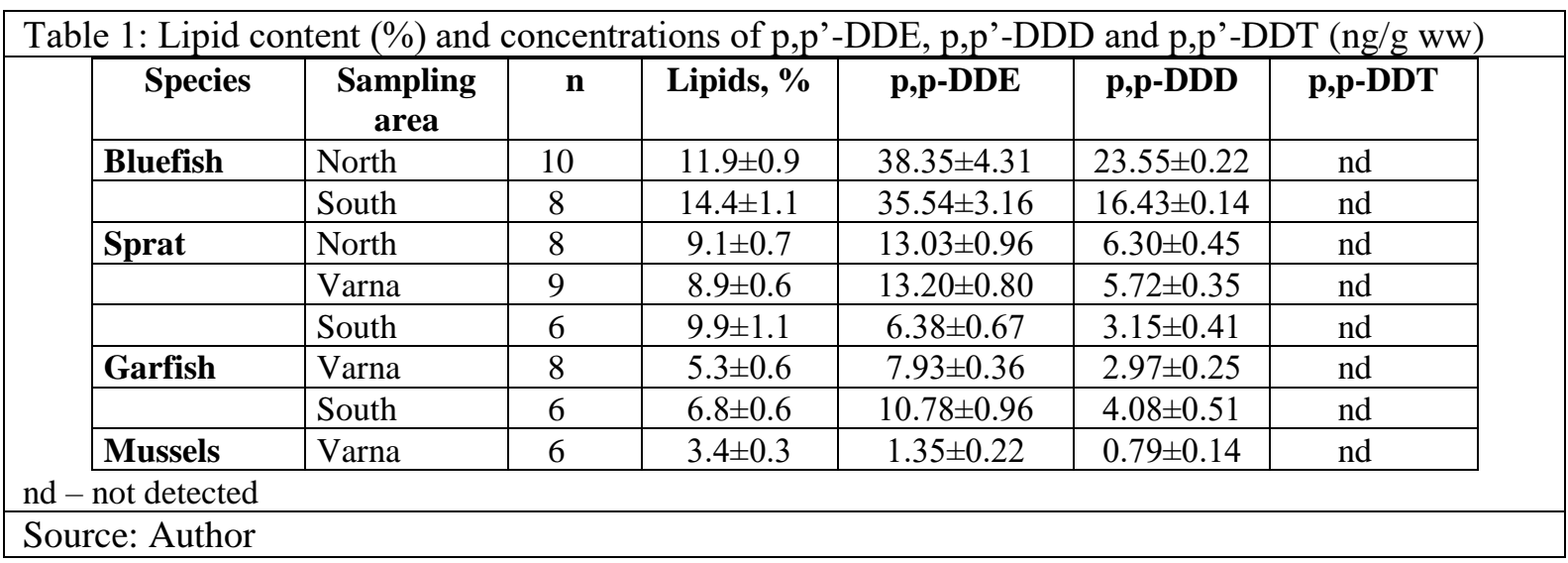

The DDE levels in bluefish were found to be relatively high, which may be due to its individual physiology characteristics and higher lipid content compared to the other fish species (average 13.2\%). The concentration of metabolite p,p'-DDD was found between 0.79 (mussels, mean value) and 19.99 ng/g ww (bluefish, mean value). The concentration of individual DDTs compounds in the sampled mussels from different part of Bulgarian Black Sea coast were described in our previous study (Georgieva, 2016), the mean values of DDTs were summarized and were presented to compare the results to the DDT levels in fish (Table 1). The concentrations of p,p-DDE and p,p-DDD detected in the soft tissue of mussels were found to be lower (1.35 and $0.79 \mathrm{ng} / \mathrm{g}$ ww, respectively) than levels in the fish samples.

The residues of DDTs metabolites were found in the order of DDE > DDD > DDT in all tested samples, and this ratio is in agreement with the results of other studies (Covaci, 2006; Georgieva, 2016). The p,pDDT was found to be below the limit of detection in all the tested samples and suggests that there is no current input of fresh DDT to the aquatic ecosystem of the Bulgarian coast of the Black Sea. The ratio $\mathrm{DDE} /$ Total DDT varied in the range from 0.63 in mussels to 0.73 in garfish. The lowest ratio was found in mussels that showed DDE/total DDT values lower than the other species. This may be due to the low metabolic capacity of the plankton to metabolize DDT (Borga, 2001) allowing a great accumulation of DDT in filtering organisms.

The sum of the DDT metabolites gave a range of concentrations from $9.5 \mathrm{ng} / \mathrm{g} \mathrm{ww}$ (sprat) to $61.9 \mathrm{ng} / \mathrm{g}$ ww in fish tissue (bluefish) and no significant differences were found between the fish species coming from different sampling areas $(\mathrm{p}>0.05)$. Hence in the current work, fish species cannot be used to assess the sources of pollution because they do not present any trend in their geographical variations. The average percent distribution of total determined DDTs among the geographical areas is $40 \%, 29 \%$ and $31 \%$ for North, Varna and South, respectively. 
The concentration of individual DDTs compounds in fish species sampled in 2007 and 2010 were described in our previous study (Georgieva, 2012; Stancheva, 2013). The data was summarized, and the mean annual concentrations of DDTs was presented for the investigated fish species in order to compare the results to the levels in 2015 (Figure 1).

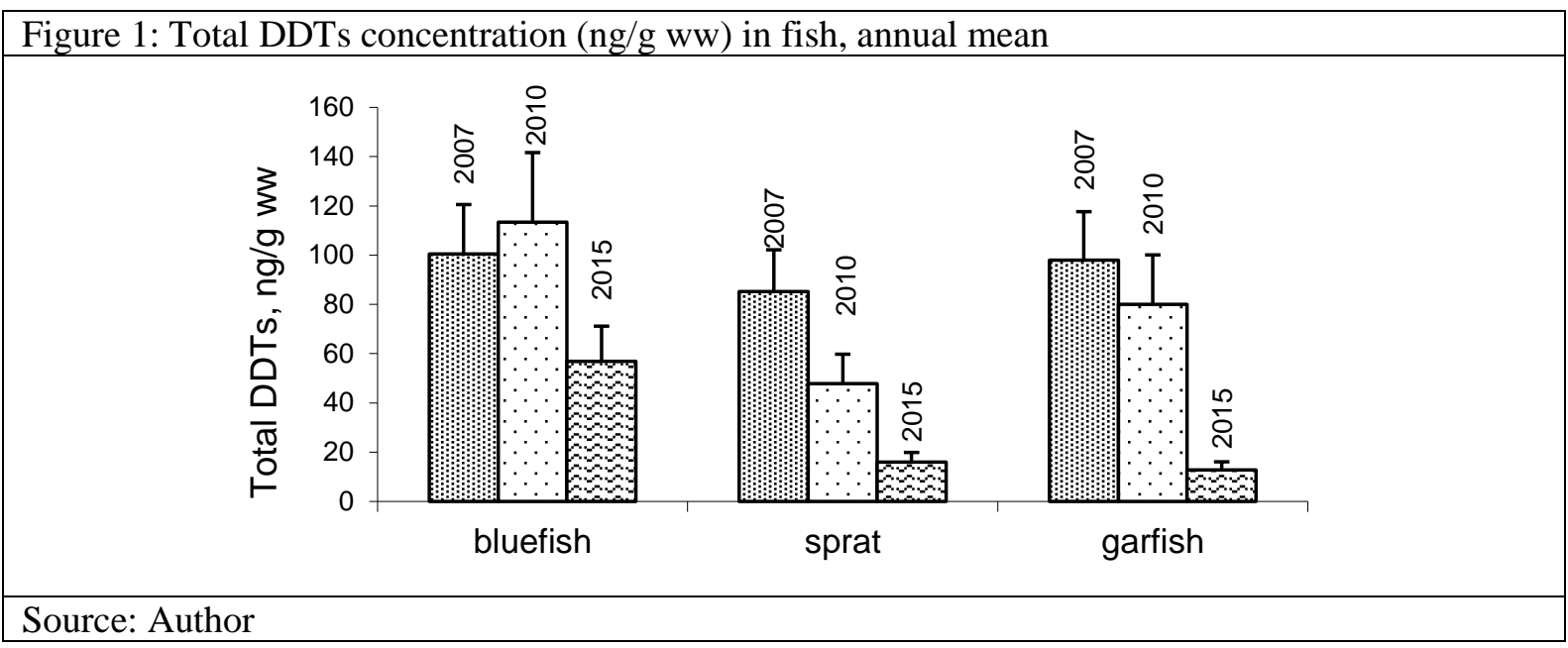

Total DDTs were found in marine fish at concentrations ranging between $12.88 \mathrm{ng} / \mathrm{g}$ wet weight (ww) (garfish 2015) and $113.31 \mathrm{ng} / \mathrm{g}$ ww (bluefish 2010). The experimental results showed significant differences $(p<0.05)$ between mean annual sum of DDTs in garfish, sprat and bluefish sampled in 2007, 2010 and 2015. Levels of DDTs in bluefish, garfish and sprat decreased in 2015.

The European Food Safety Authority recommends six PCB congeners (IUPAC Nos. 28, 52, 101, 138, 153 and 180) as suitable indicators for levels and exposure of humans when regarding non-dioxin-like PCBs (ndl-PCBs) (EFSA, 2010). These six PCB congeners have been recommended by the European Union as indicators of PCB contamination (Giandomenico, 2013). The determination of indicator PCBs is important for predicting the extent of lipophilic contamination, although their toxicity is less than that of dioxin-like PCBs (Van den Berg, 2006). The mean concentrations of indicator PCB congeners in the investigated species collected from the Black Sea in 2015 are reported in Table 2.

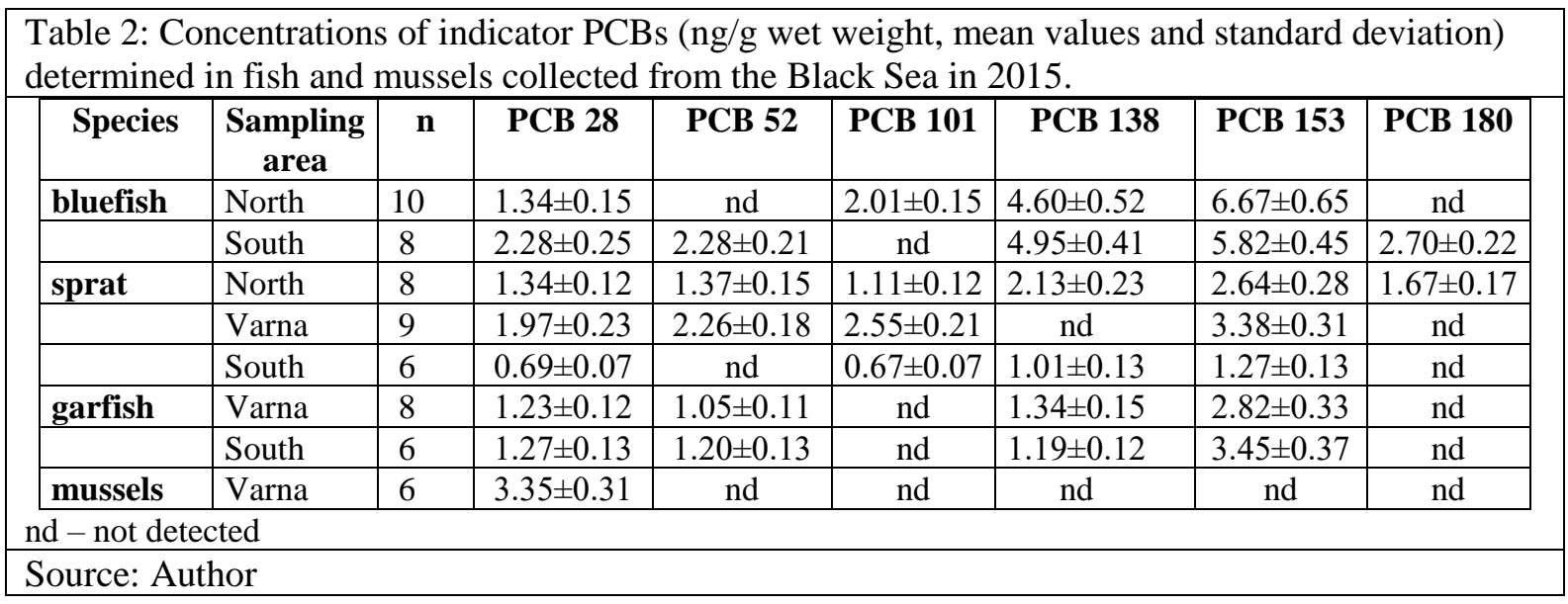

The highest I-PCBs concentration were found in bluefish (mean value $16.33 \mathrm{ng} / \mathrm{g} \mathrm{ww}$ ), a predator fish with a high lipid content. Bluefish migrate from the Marmara Sea into the Black Sea in summer (Ceyhan, 2007). Consequently, levels of pollution in this species cannot be used to assess local pollution, but they make it possible to assess the ecological status of the Black Sea ecosystem. Lower PCBs concentrations were observed in sprat $(8.02 \mathrm{ng} / \mathrm{g} \mathrm{ww})$ and garfish $(6.78 \mathrm{ng} / \mathrm{g} \mathrm{ww})$. Sprat is a species with a low trophic position and possibly accumulate relatively smaller amounts of organochlorines than the predator species investigated (Borga, 2001). Indicator polychlorinated biphenyls were found below $0.12 \mathrm{ng} / \mathrm{g}$ ww (detectable limits) in all mussel samples studied. These results are similar to a study of the Black Sea coast of Turkey, where no PCBs concentration were detected in any mussel samples. (Kurt and Ozkoc, 
2004). Our results for total indicator PCBs in the investigated fish and mussels did not exceed the maximum level of $75 \mathrm{ng} / \mathrm{g}$ wet weight (EC, 2011).

Scarce information exists on the marine toxin profiles of the Black Sea mussels from the Bulgarian coast. Recent studies showed that PSP and ASP toxins had values below the EU regulatory limit. However, according to the authors these results are not representative because mussel farms provide samples for toxicity testing only once per year. For this reason, ASP and PSP potentially could lead to shellfish intoxications during the remaining period of the year. Lack of equipment impeded the analysis of lipophilic toxins (Kalinova, 2015; Peneva, 2011).

To our knowledge this is the first attempt at an analysis of all the lipophilic toxins currently legislated in the EU in samples from the Bulgarian Black Sea coast. Summarized, the six samples were analyzed for PSP with derivatization, concentrated with derivatization and without derivatization. The six samples were analyzed for lipophilic toxins with and without concentration. Despite our efforts for different presentations of the toxins extracts, PSP, ASP, DSP and AZA were not detected in our samples. Nevertheless, it is a challenging and not a discouraging result as 1) the number of samples we collected could not give a representative result; 2) toxin causing microalgae are present on the Bulgarian Black Sea coast (Dzembekova, 2014); and 3) in the recent years there are registered cases of human shellfish poisoning (not published, oral communication). In accordance with these prerequisites our future plans for studying marine toxins include equipping the Laboratory for Marine and Aquaculture Resources, Medical University Varna for the analysis of samples from the Black sea and increasing the frequency of mussel sampling as well as plankton sampling. This initiative has the potential to optimize biotoxin monitoring, improve public health supervision, and engage the shellfish producers in helping to reduce the risk of shellfish poisoning.

\section{Conclusion}

In the presented study, DDT and its metabolites were determined as the major compounds in fish and mussel samples. The ratio DDE/DDTs ranged from 0.63 in mussel to 0.73 in garfish suggesting that there are no new inputs of DDT in the Bulgarian Black Sea coast. The results obtained show the presence of low concentrations of DDT metabolites and indicator PCBs in fish and mussel caught in the Black Sea, Bulgaria. The mean levels of I-PCBs ranged between $6.78 \mathrm{ng} / \mathrm{g}$ ww and $16.33 \mathrm{ng} / \mathrm{g} \mathrm{ww}$ (garfish and bluefish respectively). Levels of DDTs and PCBs in fish species decreased in 2010 and 2015. Importantly, the observed values of these contaminants were below the EC regulation limits. The investigated marine toxins were not detected in the analysed samples.

Further analyses are planned for the determination of marine biotoxins in mussel and plankton samples from the Bulgarian Black Sea coast. It is of paramount importance to monitor priority organochlorine compounds and marine toxins in seafood in order to protect the marine ecosystem and human health.

\section{References}

Antunes, P., \& Gil, O. (2004). PCB and DDT contamination in cultivated and wild sea bass from Ria de Aveiro, Portugal. Chemosphere, 54, 1503-1507.

Bordajandi, L., Martin, I., Abad, E., Rivera, J., \& Gonzalez, M. (2006). Organochlorine compounds (PCBs, PCDDs and PCDFs) in seafish and seafood from the Spanish Atlantic Southwest Coast. Chemosphere, 64, 1450-1457.

Borga, K., Gabrielsen, G., \& Skaare, J. (2001). Biomagnification of organchlorines along a Barents Sea food chain. Environ. Poll., 113, 187-198.

Covaci, A., Gheorghe, A., Hulea, O., \& Schepens, P. (2006). Levels and distribution of organochloride pesticides, polychlorinated biphenyls and polybrominated diphenyl ethers in sediments and biota from the Danube Delta, Romania. Environmental Pollution, 140, 136-149.

Ceyhan, T., Akyol, O., Ayaz, A., Juanes, F. (2007). Age, growth, and reproductive season of bluefish (Pomatomus saltatrix) in the Marmara region, Turkey. ICES Journal of Marine Science, 64, 531-536.

Dorea, J. (2008). Persistent, bioaccumulative and toxic substances in fish: human health considerations. Sci. Total. Environ., 400, 93-114.

Dzhembekova, N., \& Moncheva, S. (2014). Recent Trends of potentially toxic phytoplankton species along the Bulgarian Black Sea area. Proceeding from the 12th Conference on marine sciences and technologies, 321-329.

EC. (2011, december). Commission Regulation (EU) No 1259/2011 amending regulation (EC) no. 1881/2006 as regards maximum levels for dioxins, dioxin-like PCBs and non dioxin-like PCBs in foodstuffs. Official Journal of the European Union, L320, 18-23.

EFSA. (2010). Monitoring of Non Dioxin-Like PCBs in Food and Feed. EFSA Journal, 8(7), 1701. 
Ferrante, M., Sciacca, S., Fallico, R., Fiore, M., \& Conti, G. (2013). Harmful Algal Blooms in the Mediterranean Sea: Effects on Human Health. 2, 587. doi:10.4172/scientificreports

Georgieva, S., Stancheva, M., \& Makedonski, L. (2012). Organochlorine pesticides and PCBs in marine fish. Ovidius University Annals of Chemistry, 23(1), 92-98.

Georgieva, S., Stancheva, M., \& Makedonski, L. (2016). Investigation about the presence of organochlorine pollutants in mussels from the Black Sea, Bulgaria. Ovidius University Annals of Chemistry, 27(1), 8-12.

Giandomenico, S., Spada, L., Annicchiarico, C., Assennato, G., Cardellicchio, N., Ungaro, N., \& Di Leo, A. (2013). Chlorinated compounds and polybrominated diphenyl ethers (PBDEs) in mussels (Mytilus galloprovincialis) collected from Apulia Region coasts. Marine Pollution Bulletin, 73, 243-251.

Huss, H. (1997). Control of indigenous pathogenic bacteria in seafood. Food Control, 18, 91-98.

Kalinova, G., Mechkarova, P., \& M., M. (2015). A study of paralytic toxins in cultured mussels from Bulgarain Black Sea. Trakia Journal of Sciences, 13, 303-308.

Krock, B., Seguel, C. G., \& Cembella, A. D. (2007). Toxin profile of Alexandrium catenella from the Chilean coast as determined by liquid chromatography with fluorescence detection and liquid chromatography coupled with tandem mass spectrometry. Harmful Algae, 6(5), 734-744.

Krock, B., Tillmann, U., John, U., \& Cembella, A. D. (2008). LC-MS-MS aboard ship: tandem mass spectrometry in the search for phycotoxins and novel toxigenic plankton from the North Sea. Anal. Bioanal. Chem., 392(5), 797-803.

Kurt, P., \& Ozkoc, H. (2004). Kurt, P., Ozkoc, H. A survey to determine levels of chlorinated pesticides and PCBs in mussels and seawater from the Mid-Black Sea Coast of Turkey. Marine Pollution Bulletin, 48, 1076-1083.

Marques, A., Nunes, M., Moore, S., \& Strom, M. (2010). Climate change and seafood safety: Human health implications. Food Research International, 43, 1766-1779.

Marques, A., Rosa, R., \& Nunes, M. (2013). Seafood Safety and Human Health Implications. The Meditarranean Sea, 589603.

Merdzhanova, A., Ivanov, I., Dobreva, D., \& Makedonski, L. (2017). Fish Lipids as a valuable source of polyunsaturated fatty acids. Acta Scientifica Naturalis, 4(1), 70- 75.

Mons, M., Van Egmond, H., \& Speijers, G. (1998). Paralytic shellfish poisoning: A review. Bilthoven: RIVM. Retrieved from https://www.rivm.nl/dsresource?objectid=37bff122-624c-4f9d-93af-0c869c412d76\&type=org\&disposition=inline Naccari, F., Giofre, F., Licata, P., Martino, D., Calo, M., \& Parisi, N. (2004). Organochlorine pesticides and PCBs in wild boars from Calabria (Italy). Environmental Monitoring and Assessment, 96, 191.

Nadal, M., Marquès, M., Mari, M., \& Domingo, J. L. (2015). Climate change and environmental concentrations of POPs: A review. Environmental Research, 143(Part A), 177-185.

Okay, O., Karacık, B., Basak, S., Henkelmann, B., Bernhöft, S., \& Schramm, K. (2009). PCB and PCDD/F in sediments and mussels of the Istanbul strait (Turkey). Chemosphere, 76, 159-166.

Peneva, V., Gogov, Y., Kalinova, G., \& Slavova, A. (2011). Application of HPLC method for determination of ASP toxins in bivalve mollusks. Sofia: Jubilee Scientific Session 110 Years NDNIVMI.

Stancheva, M., Georgieva, S., \& Makedonski, L. (2013). Organochlorine pollutants in fish from Bulgarian region of the Black Sea. Quality Assurance and Safety of Foods and Crops, 5(3), 243 - 251.

Stancheva, M., Georgieva, S., \& Makedonski, L. (2017b). Polychlorinated biphenyls in fish from Black Sea, Bulgaria. Food Control, 72, 205-210. doi:10.1016/j.foodcont.2016.05.012

Stancheva, M., Merdzhanova, A., \& Dobreva, D. (2017a). Fat soluble vitamins, cholesterol and fatty acid composition of wild and farmed Black mussel (Mytilus galloprovincialis) consumed in Bulgaria. Journal of Aquatic Food Product Technology, 26(2), 181-191.

Suárez, P., Ruiz, Y., Alonso, A., \& San Juan, F. (2013). Organochlorine compounds in mussels cultured in the Rна of Vigo: Accumulation and origin. Chemosphere, 90, 7-19.

Turner, J., Sibbald, R., \& Hemens, J. (1986). Chlorinated secondary domestic sewage effluent as a fertilizer for marine aquaculture: III. Assessment of bacterial and viral quality and accumulation of heavy metals and chlorinated pesticides in cultured fish and prawns. Chemosphere, 53, 157-168.

UNEP. (2001). Stockholm Convention on Persistent Organic Pollutants. Geneva: Stockholm Convention. Retrieved from http: //chm.pops.int/Home/tabid/2121/mctl/ViewDetails/Event-ModID/871/EventID/230/xmid/6921/Default.aspx.

Van Ael, E., Covaci, A., Blust, R., \& Bervoets, L. (2012). Persistent organic pollutants in the Scheldt estuary: Environmental distribution and bioaccumulation. Environmental International, 48, 17-27.

Van den Berg, M., Birnbaum, L., Denison, M., De Vito, M., Farland, W., Feeley, M., \& al., e. (2006). The 2005 World Health Organization reevaluation of human and Mammalian toxic equivalency factors for dioxins and dioxin-like compounds. Toxicology Science, 93(2), 223-241.

Zelníčková, L., Svobodová, Z., Maršálek, P., \& Dobšíková, R. (2015). Persistent organic pollutants in muscle of fish collected from the Nové Mlýny reservoir in Southern Moravia, Czech Republic. Environ. Monit. Assess., 187, 448. 